Article

\title{
Obesity Risk Assessment Tool for Low-Income Spanish Speaking Immigrant Parents with Young Children: Validity with BMI and Biomarkers of Obesity
}

\author{
Marilyn S. Townsend ${ }^{1, *}$, Mical K. Shilts ${ }^{2}$, Louise Lanoue ${ }^{1}$, Christiana Drake $^{3}$, \\ L. Karina Díaz Rios ${ }^{4}$ (D), Dennis M. Styne ${ }^{5}$, Nancy L. Keim ${ }^{6}$ and Lenna Ontai ${ }^{7}$ \\ 1 Department of Nutrition, University of California, Davis, CA 95616, USA; 1lanoue@ucdavis.edu \\ 2 Department of Family and Consumer Sciences, Nutrition, Food \& Dietetics Program, California State \\ University Sacramento, Sacramento, CA 95819, USA; shiltsm@csus.edu \\ 3 Department of Statistics, University of California at Davis, Davis, CA 95616, USA; cmdrake@ucdavis.edu \\ 4 Division of Agriculture and Natural Resources, Public Health Department, University of California, Merced, \\ CA 95343, USA; kdiazrios@ucmerced.edu \\ 5 Pediatric Endocrinology, Department of Pediatrics, University of California, Davis Medical Center, \\ Sacramento, CA 95817, USA; dmstyne@ucdavis.edu \\ 6 USDA Western Human Nutrition Research Center, University of California, Davis, CA 95616, USA; \\ nancy.keim@usda.gov \\ 7 Department of Human Ecology, University of California, Davis, CA 95616, USA; lontai@ucdavis.edu \\ * Correspondence: mstownsend@ucdavis.edu
}

Received: 1 October 2020; Accepted: 18 November 2020; Published: 22 November 2020

check for updates

\begin{abstract}
Children of Hispanic origin bear a high risk of obesity. Child weight gain trajectories are influenced by the family environment, including parent feeding practices. Excessive body fat can result in unhealthful metabolic and lipid profiles and increased risk of metabolic diseases. The objective was to estimate criterion validity of an obesity risk assessment tool targeting Spanish-speaking families of Mexican origin using anthropometric measures and blood values of their young children. A cross-sectional study design with five data collection sessions was conducted over an eight-week period and involved 206 parent/child dyads recruited at Head Start and the Special Supplemental Nutrition Program for Women, Infants and Children in Northern California. Main outcome measures were criterion validity of Niños Sanos, a pediatric obesity risk assessment tool, using anthropometric measures and blood biomarkers. Niños Sanos scores were inversely related to child BMI-for-age percentiles $(p=0.02)$, waist-for-height ratios $(p=0.05)$ and inversely related to blood biomarkers for the metabolic index $(p=0.03)$ and lipid index $(p=0.05)$ and positively related to anti-inflammatory index ( $p=0.047)$. Overall, children with higher Niños Sanos scores had more healthful lipid, metabolic and inflammatory profiles, as well as lower BMI-for-age percentiles and waist-to height ratios, providing evidence for the criterion validity of the tool. Niños Sanos can be used by child obesity researchers, by counselors and medical professionals during clinic visits as a screening tool and by educators as a tool to set goals for behavior change.
\end{abstract}

Keywords: child obesity prevention; evaluation; Hispanic; low-income families; pre-school; risk assessment; validation; Spanish

\section{Introduction}

In the U.S., Hispanic children, 2-19 years old, have the highest prevalence of $>85$ th BMI percentile $(46 \%)$. This rate is far greater than the national average of $35 \%$ for children and that measured in 
non-Hispanic white children of 30\% [1]. Of great concern is the sharp increase in obesity rates $>95$ th percentile BMI in 2-5 year-old children, with Hispanics having a higher prevalence across nearly all classes of obesity and all years between 1999 and 2016 [1,2]. Given that early childhood obesity strongly predicts adolescent and young adult obesity [3] and recognizing that this young age may be ideal for intervention, the Institute of Medicine (IOM) and the American Academy of Pediatrics (AAP) recommended the development of assessment tools targeting families' modifiable environmental and behavioral factors associated with the risk of pediatric obesity $[4,5]$. Although many factors have been associated with the development of childhood obesity, excessive caloric intake and/or inadequate physical activity remain the main drivers [6]. Moreover, Hispanic children are disproportionate carriers of genetic variants which predispose them to early onset obesity and fatty liver [7,8]. Elevated BMI in children does not always relate to central obesity [9]. Moreover, waist circumference normalized to height has been an indicator of increased cardiovascular risk in children. However, this anthropometric value may not fully capture the different distribution of body fat, particularly the metabolically active visceral fat that releases mediators, i.e., adipokines. These adipokines in blood have been linked to metabolic dysregulation, dyslipidemia and chronic low-grade inflammation $[10,11]$. These biomarkers have the potential to be more sensitive indicators of metabolic disturbances in response to obesogenic behaviors than anthropometric measures alone; biomarkers inform adipose tissue dysfunction rather than reflect the accumulation of body fat [10]. Children with obesity tend to have higher circulating blood insulin and leptin levels and may develop resistance to the actions of insulin and leptin [12]. As insulin is critical for cellular glucose uptake and to prevent efflux of fat from the adipose tissue, also known as lipolysis inhibition, children with insulin resistance are at risk of developing type 2 diabetes and cardiovascular complications at an earlier age. HOMA-IR (homeostatic model assessment of insulin resistance) and triglycerides to HDLC ratio (TGHDL) are valid clinical surrogates of insulin resistance and are predictors of metabolic syndrome and cardiovascular risks in children [12,13]. In children, high levels of leptin and insulin are often associated with low levels of adiponectin and high levels of resistin, as obesity is a condition that modulates the secretion of both adipokines, which exacerbates insulin resistance $[14,15]$. Hence, the leptin to adiponectin ratio is a better marker of body fat and of comorbidity risk in children $[12,16]$. In addition to antagonizing the action of insulin, resistin is an inflammatory molecule that promotes inflammation and inflammatory diseases [17]. In addition, children with overweight or obesity tend to have lower concentrations of IL-10 and IGFBP-1 [12,18-21], which can predispose them to low grade inflammation often reflected in higher circulating levels of CRP and resistin [22,23]. Longitudinal studies have shown that children with high BMI have increased risk of cardiovascular disease in adulthood [24]. Of greater concern is the observation that dyslipidemia, insulin resistance and inflammation may begin in childhood for children with obesity. As such, biomarkers in complement to anthropometric measures are useful for the validation of behavioral assessment tools to identify the children who are at higher risk of developing obesity-related diseases including metabolic syndrome, cardiovascular problems, and asthma $[4,10,25]$.

Parents influence young children's growth trajectories by shaping the home environment, controlling food availability and promoting healthy behaviors [26]. As such, parents play a critical role in establishing the lifestyle behaviors that influence obesity risks and are practiced in the home environment. For Hispanic low-income households, parent socioeconomic and education status are critical factors influencing the obesity risk in children [27]. Hispanic participation in food assistance programs has been reported to be lower than among the general eligible population [28]. At the same time, Hispanic households report some of the highest rates of food insecurity [29]. In response to the staggering obesity rates among children, Congress authorized federal programs to include an obesity prevention focus in their programs for families with young children. These programs include: Head Start [30]; Special Supplemental Nutrition Program for Women, Infants and Children (WIC) [31]; Supplemental Nutrition and Assistance Program-Education (SNAP-Ed) [32]; and Expanded Food and Nutrition Education Program (EFNEP) [33]. These four programs have a presence in all or most low-income communities in the U.S. Consequently, they have the potential to impact obesity prevalence 
among participants [34]. In response to the identified need for valid assessment tools targeting families enrolled in these federal programs, a pediatric obesity risk assessment tool, Healthy Kids, replete with visuals that replace and clarify text [35] making it suitable for families with limited written English literacy, was created using the results from two extensive literature reviews [36,37], and cognitive interviews with low-income English-speaking parents [38,39]. Healthy Kids was demonstrated to be reliable and valid using the objective measures, inflammatory biomarkers [40] and BMI [41], and subjective measures, 24-h dietary recalls and 36-h activity logs [41].

\section{Objectives}

The current study is addressing this need for valid tools for low-income Spanish-speaking immigrant families in California. It is based on the above Healthy Kids research and includes visuals making it suitable for Hispanic families with limited English proficiency and a range of literacy skills in their main language, Spanish. In community settings, participant literacy drives the need for a tool with appropriate readability [42]. Evaluation and risk identification were two priorities for federal program participants while simultaneously having a low response burden for participants. Study objectives include selecting appropriate items from the pool of 45 items for a final parsimonious version, now called Niños Sanos, and establishing criterion validity of the final version of the Niños Sanos tool with low-income Spanish-speaking children and their families. Specifically, four hypotheses are tested: (1) Niños Sanos total score is associated with child body mass index (BMI) for-age percentiles and waist-to-height ratios with a lower Niños Sanos score predicting a higher BMI-for-age percentile; (2) Niños Sanos total score is associated with a child metabolic biomarker index with a lower Niños Sanos score indicating a less healthful, metabolic index score; (3) Niños Sanos total score is associated with a child lipid biomarker index with a lower Niños Sanos score indicating a less healthful, index score; and (4) Niños Sanos total score is associated with a child anti-inflammatory biomarker index with a higher Niños Sanos score indicating a more healthful, anti-inflammatory index score. Accordingly, we hypothesize that a lower Niños Sanos score, i.e., less healthful behaviors, is associated with children having a less healthful metabolic, lipid and inflammatory status and higher BMI compared to children with higher Niños Sanos scores.

\section{Materials and Methods}

\subsection{Participants}

Participants ( $n=273$ parent-child dyads) were recruited by direct solicitation and at information sessions at Head Start $(n=21)$ and WIC sites $(n=3)$ in 2 counties in northern California. The adults were parents or caregivers, $\geq 18$ years, who declared Spanish as their preferred language, had at least one child aged $3-5$ years and were low-income verified by participation in at least one federal assistance program for low-income residents.

\subsection{Study Design, Timeline \& Data Collection}

Participants were recruited over the course of a year. For an individual parent/child dyad, data were collected in this 8 -week cross-sectional study at 5 data collection points interspaced approximately 1-2 weeks apart as shown in Supplemental Table S1. At week 1, parents completed a demographic questionnaire as, well as the first child's 36-h physical activity/screen time/bedtime logs and child's 24-h dietary recalls [43]. The 36-h activity log and 24-h diet recall were administered again at weeks 5 and 7, for a total of 3 child 36-h activity logs and 3 child 24-h dietary recalls, the results of which will be reported elsewhere. The 45-item pediatric obesity risk assessment tool, Niños Sanos [44], was administered to parents at week 3 along with a food behavior checklist previously shown to be valid with Spanish-speaking immigrants [45-47]. Anthropometry and blood samples were collected from fasted children at the last time point around 8 weeks after the onset of week 1 of data collection. Each session lasted roughly one hour and data were collected in person and by phone interviews. 
All communications and documentation such as consent forms, assessment tools, questionnaires and logs were in Spanish and collected by trained research staff who spoke Spanish as a first language. The protocol, ID \#693978-14, was approved by the Institutional Review Board of the University of California and participants provided a signed consent at enrollment and were given monetary stipends as compensation for their time and effort.

\subsection{Biopsychosocial Framework}

The framework used for the design of this validation research of Niños Sanos was based on systems theory $[48,49]$. This Niños Sanos framework considered the health of the child in the context of the family environment (Figure 1) and in that respect is similar to the Socio-Ecological Model (SEM) used to guide development of the tool's content [50]. In hierarchical steps, this framework recognizes that the parent's relevant behaviors create the environment for the 3-5 year old child and this, in turn, guides the child's eating and activity behaviors [44]. In turn, the young child's eating behaviors subsequently drive his/her food intake, measured by 3 National Cancer Institute's automated self-administered 24-h (ASA24) diet recalls [51], resulting in intakes of macro and micronutrients. The parent's control over the child's physical, screen and sleep activities drives the child's activity behaviors measured by 3 36-h activity logs [43]. Participant data obtained directly from the child employing objective measures are tinted blue and purple. Participant data collected from the parent about the child employing self-report/subjective measures are lime green and aqua. Thus, as specified by this Niños Sanos framework, intake of nutrients and physical activity/screen/sleep behaviors by the child can influence the child's anthropometric and biochemical markers of childhood obesity, which then impacts the child's health status. Figure 1 provides a graphic of the Niños Sanos framework.

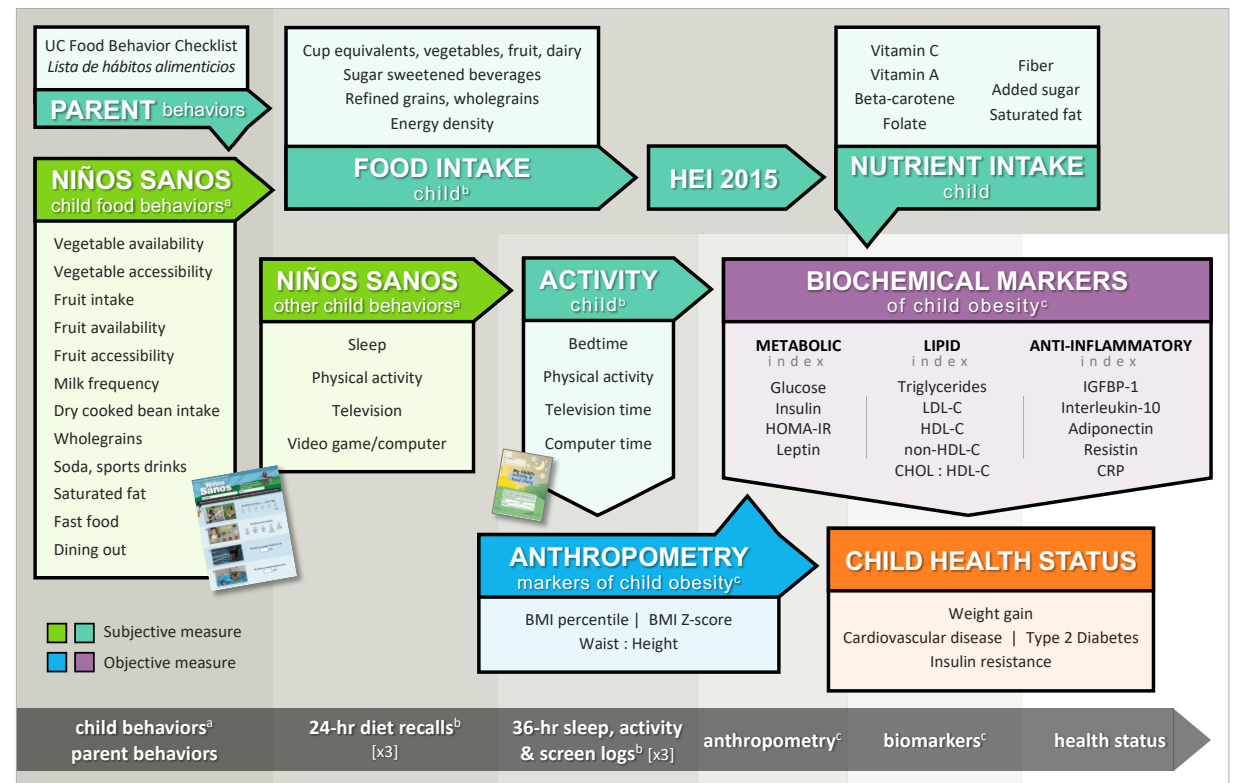

Figure 1. Biopsychosocial framework for validation of Niños Sanos targeting immigrant families with preschool-aged children. ${ }^{a}$ Child dietary, physical activity, sleep and screen behaviors collected with

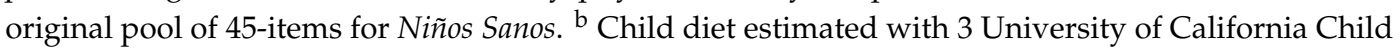
Eating and Activity Diary and the National Cancer Institute's Automated Self-Administered 24-h (ASA24) diet recalls. Child physical, screen, and sleep activities were estimated with 3 36-h activity logs using same Diary. ${ }^{\mathrm{c}}$ Child height, weight, waist, blood, blood pressure and body temperature were collected. Abbreviations: HEI: healthy eating index; ASA24: automated self-administered 24-h dietary assessment tool; HOMA-IR, homeostatic model assessment of insulin resistance; LDL-C, low density lipoprotein cholesterol; HDL-C, high density lipoprotein cholesterol; non-HDL-C, non-high density lipoprotein cholesterol; CHOL:HDL-C, cholesterol to high density lipoprotein cholesterol ratio; IGFBP-1, insulin-like growth factor binding protein-1; IL10, interleukin 10; CRP, C-reactive protein. 


\subsection{Child Anthropometry}

The child's height, weight and waist were measured by trained observers using a portable stadiometer (Seca Road Rod, Seca Medical Measurement Systems \& Scales, Hanover, MD, USA), a digital scale (Seca Carisma Model 810, Seca Medical Measurement Systems \& Scales, Hanover, MD, USA) and body measuring tape (Creative Health Products, Ann Arbor, MI, USA). Children were measured in light clothing, no jackets or outerwear, without shoes. Weights were recorded to the nearest $0.1 \mathrm{~kg}$ and heights and waist circumferences were measured twice to the nearest $0.1 \mathrm{~cm}$ with the child fully erect, head in the Frankfort Plane and at the end of a deep inhalation. Waist measurement was taken at the narrowest portion of the torso, between the top of the child's hip bone and lowest rib, bringing the tape measure around the body, level with the belly button, on children breathing normally. Waist-to-height ratio was calculated as $100 \times$ waist $(\mathrm{cm}) /$ height $(\mathrm{cm})$. Body mass index $(\mathrm{BMI})\left(\mathrm{kg} / \mathrm{m}^{2}\right)$ and waist-to-height $(\mathrm{cm} / \mathrm{m})$ ratio were calculated using the average of the measurements. BMI-for-age percentiles were derived using the Centers for Disease Control and Prevention (CDC)'s BMI percentile calculator for children [52]. BMI z-scores were calculated from the CDC pediatric growth charts using the CDC SAS codes [53]. CDC BMI-for-age percentile cut points were used to determine the weight status of each child (obesity, 95th percentile; overweight, 85th to less than the 95th percentile; normal weight, 5 th percentile to less than the 85 th percentile; and underweight, less than the 5 th percentile).

\subsection{Child Blood Biomarkers}

For this study, an expert team selected biomarkers from the literature based on the association with child BMI. The biomarkers used for the current analyses are a subset and include: glucose, insulin, leptin, triglycerides (TG), high-density lipoprotein cholesterol (HDL-C), low-density lipoprotein cholesterol (LDL-C) and non-high-density lipoprotein cholesterol (non-HDL-C) [22,54]. Insulin-like growth factor binding protein-1 (IGFBP-1), interleukin-10 (IL-10), adiponectin, C-reactive protein (CRP) and resistin were also included [18,55-57]. Sources, targets and biological actions of these biomarkers as well as their relationship to children's BMI are summarized in Table 1.

Table 1. Characteristics and evidence for the selection of the biomarkers included in the metabolic, lipid and anti-inflammation indices.

\begin{tabular}{|c|c|c|c|c|}
\hline & Sources & Targets & Biological Actions & $\begin{array}{l}\text { Relationship to } \\
\text { BMI in Children }\end{array}$ \\
\hline \multicolumn{5}{|c|}{ Metabolic index } \\
\hline Glucose & Diet, Liver, Muscle & Cells & Energy & Positive [22] \\
\hline Insulin & Pancreas & Muscle, AT & $\begin{array}{l}\text { Glycemia homeostasis, } \\
\text { lipolysis inhibition }\end{array}$ & Positive $[22,54]$ \\
\hline HOMA-IR & $\mathrm{n} / \mathrm{a}$ & $\mathrm{n} / \mathrm{a}$ & Insulin sensitivity index & Positive $[22,54]$ \\
\hline Leptin & AT & $\begin{array}{c}\text { Brain } \\
\text { (hypothalamus), } \\
\text { Muscle, AT, liver }\end{array}$ & $\begin{array}{c}\text { Regulation of food intake, } \\
\text { satiety and energy } \\
\text { expenditure }\end{array}$ & Positive [22] \\
\hline $\begin{array}{c}\text { Leptin: } \\
\text { Adiponectin }\end{array}$ & $\mathrm{n} / \mathrm{a}$ & $\mathrm{n} / \mathrm{a}$ & $\begin{array}{l}\text { Adipose tissue dysfunction } \\
\text { index }\end{array}$ & Positive [55] \\
\hline TG: HDL-C & $\mathrm{n} / \mathrm{a}$ & $\mathrm{n} / \mathrm{a}$ & Insulin resistance index & Positive [56] \\
\hline \multicolumn{5}{|c|}{ Lipid index } \\
\hline Triglycerides & (Diet), Liver, AT & AT & Energy & Positive $[22,54]$ \\
\hline LDL-C & Plasma & Cells, Liver & Cholesterol transport (influx) & Positive [22] \\
\hline HDL-C & Plasma & Liver & Cholesterol transport (effux) & Negative $[22,54]$ \\
\hline Non-HDL-C & Gut, Liver & Cells, Liver & Cholesterol transport (influx) & Positive [22] \\
\hline
\end{tabular}


Table 1. Cont.

\begin{tabular}{ccccc}
\hline & Sources & Targets & Biological Actions & $\begin{array}{c}\text { Relationship to } \\
\text { BMI in Children }\end{array}$ \\
\hline CHOL:HDL-C & n/a & n/a & Pro-atherogenic index & Positive [22] \\
\hline IGFBP-1 & Liver & Muscle, AT & $\begin{array}{c}\text { Insulin sensitivity, } \\
\text { anti-inflammatory }\end{array}$ & Negative [57] \\
\hline Interleukin-10 & AT, Spleen & Liver & Anti-inflammatory & Negative [18] \\
\hline Adiponectin & AT & $\begin{array}{c}\text { Pancreas, Muscle, } \\
\text { Liver, AT }\end{array}$ & $\begin{array}{c}\text { Anti-inflammatory, insulin } \\
\text { sensitivity }\end{array}$ & Negative [22,54] \\
\hline CRP & Liver & Muscle, AT & $\begin{array}{c}\text { Pro-inflammatory, insulin } \\
\text { resistance }\end{array}$ & Positive [22] \\
\hline Resistin & AT & AT & Insulin resistance, food intake & Positive [14]
\end{tabular}

Abbreviations: AT, adipose tissue; HOMA-IR, homeostatic model assessment of insulin resistance; LDL-C, low density lipoprotein cholesterol; HDL-C, high density lipoprotein cholesterol; TG: HDL-C, triglyceride: high density lipoprotein cholesterol ratio; non-HDL-C, non-high density lipoprotein cholesterol; CHOL:HDL-C, cholesterol to high density lipoprotein cholesterol ratio; IGFBP-1, insulin-like growth factor binding protein-1; IL10, interleukin 10; CRP, C-reactive protein.

\subsection{Calculated Biomarkers}

LDL-C was calculated using the Friedewald equation as total cholesterol (mg/dL) - HDL-C $(\mathrm{mg} / \mathrm{dL})-\mathrm{TG}(\mathrm{mg} / \mathrm{dL}) / 5$. Non-HDL-C is the total cholesterol minus HDL-C. HOMA-IR (homeostatic model assessment for insulin resistance) [58] was calculated as fasting insulin $(\mu \mathrm{IU} / \mathrm{mL}) \times$ fasting glucose $(\mathrm{mmol} / \mathrm{mL}) / 22.5$. Cholesterol to HDL-C, triglycerides to HDL-C and leptin to adiponectin ratios were generated.

\subsection{Blood Collection, Storage, Analysis}

About $30 \mathrm{~mL}$ of blood was collected from fasted children into 3 vials via venipuncture by a certified pediatric phlebotomist from the University of California Davis Clinical Trial Center. Body temperature was taken to rule out potential illnesses as confounders. Vacutainers containing serum were left at room temperature $30 \mathrm{~min}$ to allow clotting and stored on ice for transport along with iced plasma tubes to the laboratory at the USDA Western Human Nutrition Research Center on the University of California at Davis campus, where the respective serum and plasma samples were recovered by centrifugation $\left(15 \mathrm{~min}\right.$ at $1500 \times \mathrm{g}$ at $\left.4{ }^{\circ} \mathrm{C}\right)$. Samples were aliquoted and stored at $-80^{\circ} \mathrm{C}$ for later analyses. Plasma glucose and lipids were measured by standardized enzymatic assays at the University of California Davis Medical Center. Serum insulin, leptin and adiponectin and plasma IGFBP-1 and IL-10 were measured by electro-chemiluminescent immunoassay using standard and custom single and multiplex panels (Meso Scale Discovery, MSD, Rockville, MD, USA). Biomarkers were analyzed in triplicates (IGFBP-1 in duplicates) with the selection of the best 2 of 3 , if necessary, to reduce the coefficient of variability $(\mathrm{CV})$ to less than $5 \%$ for all parameters (IGFBP-1, less than 10\% CV). The multiplex assays required 7 plates for the analysis of the full data set. An internal control was added to each plate to adjust for plate-to-plate variability. There were no outliers, defined as values smaller or greater than 1.5 times the interquartile range above the upper quartile or below the lower quartile, in our data set.

\subsection{Biomarker Indices}

The biomarkers raw data were standardized using z-scores which enabled us to combine multiple biomarkers of different units into metabolic, lipid and inflammation indices. From a biological standpoint, the use of a cumulative index provides greater accuracy assessment of health status while decreased variability may increase the likelihood of a stronger correlation between variables than a single biomarker [59]. The metabolic index was the sum of z-scores of glucose, insulin, leptin, leptin to 
adiponectin ratio, triglycerides-to-HDL-C ratio and HOMA-IR. The lipid index was calculated as the sum of HDL-C (HDL-C z-scores multiplied by -1 to correct for its inverse association with the index), LDL-C, non-HDL-C cholesterol, cholesterol to HDL-C ratio and triglycerides. The anti-inflammatory index was the sum of the z-scores of adiponectin, IGFBP-1, IL-10, CRP and resistin. CRP and resistin $z$-scores were multiplied by -1 for inclusion in the anti-inflammatory index. The biomarker indices are summarized in Table 1.

\subsection{Niños Sanos Cultural Adaptation and Face Validation}

To ensure that Niños Sanos was acceptable for use by Spanish-speaking parents, Healthy Kids [60] was adapted following an iterative process with three components-forward translation, equivalence verification and cognitive interviews. The tool was forward translated by 2 bilingual and bicultural Spanish speakers and the photos were substituted with culturally appropriate images of families, activities and food items. Three content experts (i.e., child nutrition, developmental psychology) verified the translated tool to ensure it remained conceptually equivalent to Healthy Kids. The expert-verified tool was presented to Spanish-speaking parents who participated in one-on-one cognitive interviews. Twenty-three parents were recruited from 4 local Head Start preschool programs in a metropolitan area in Northern California and received $\$ 10$ as compensation. After each round of cognitive interviews, changes to the tool were proposed and reviewed by content experts for equivalence verification. A new version that reconciled feedback from cognitive interviews and input from experts was created and used in a subsequent round of cognitive interviews with a new set of parents. This process was iterated four times until all items in Niños Sanos were deemed acceptable by both parents and content experts, at which point face validity was established.

\subsection{Item Reduction for Niños Sanos}

The 45 items on Ninos Sanos represented a pool of behaviors for 10 constructs compiled from 3 extensive literature reviews [36,37]. There were multiple items for each construct. To create this parsimonious tool appropriate for a low-income Spanish-speaking population in a community setting, item reduction was employed to produce a data driven, lower respondent burden version of Niños Sanos with 16-20 relevant items. Each of the items in the 45-item pool was coded on a 5-point scale, the highest score indicative of the healthier behavior, and discretized into categories. Boxplots were generated for each of the Niños Sanos 45 items and against the child anthropometric measures, i.e., BMI-for-age percentile, BMI z-scores and waist to height ratios. Items were deemed relevant if the boxplots showed a positive association with one or more of these anthropometric markers, i.e., when a higher score for a given item was associated with a lower BMI percentile-for-age, BMI z-score, or waist-to-height ratio. For example, the 45 -item pool contained 9 fruit and vegetable items representing different fruit and vegetable behaviors published in the literature [37]; the 18-item tool contained 4 items for this construct.

\subsection{Sample and Attrition}

Families $(n=273)$ were enrolled in the study with 206 parent/child dyads completing the 5 data collection time points (to week 8), as shown in Supplemental Figure S1. The retention rate was $78 \%$. At a significance level of $p=0.05$, tests for attrition revealed that participants who remained in the study $(n=206)$ were not different for most demographic variables tested with two exceptions. Parents remaining in the study were more likely to report being unemployed compared to parents who dropped from the study $(n=67)$. In addition, parents in the study were slightly older than parents leaving the study (+2 years). Additional tests showed no difference to Niños Sanos scores between parents remaining in the study $(n=241)$ and those $(n=32)$ that dropped after week $1(p=0.63)$ (Supplemental Figure S1). From the final data set $(n=206), 202$ parents completed all items on the Niños Sanos tool. Anthropometry was successfully measured on 200 children with some missing data due to fussy children or imprecise measures. Although 190 children donated a blood sample, the 
number of observations for biomarkers ranged between 159 to 163; missing data $(n=37-45)$ were due to insufficient amount of blood collected, parent refusal or child fussiness during blood draws and insufficient plasma and serum recovered during processing.

\subsection{Statistics}

Descriptive statistics were calculated as means with standard deviations and medians with interquartile range for continuous variables, or as frequencies and percent for categorical variables. Pearson's Chi-squared test for association and t-tests were employed to compare demographic data between dropout and final samples. Logistic regression was used in a multivariate model to assess the effects of several covariates on dropouts. Sample size estimates for the main hypothesis of this study, a relationship of BMI-for-age percentiles with Niños Sanos high and low scores, were based on data from our previous work with English speaking families and Healthy Kids [41]. With at least 200 children, i.e., 100 in each group, this study was powered at $80 \%$ to detect a partial $R^{2}$ of 0.08 or larger due to Niños Sanos scores. Boxplots of BMI-for-age percentiles were created across each of the 45 Niños Sanos items to illustrate the direction of the findings to define low and high Niños Sanos behavior scores. Preliminary analyses between the biomarker index z- scores and Niños Sanos showed that the relationships between these variables and the Niños Sanos high and low scoring groups were non-linear. Monotone transformations were tested using log, squared and square root. No transformation of the anthropometric and biomarker variables could be identified that provided an acceptable fit for a regression model with these data for the 18-item Niños Sanos scale; consequently, non-parametric tests were employed. The relationship between child anthropometry variables, i.e., BMI-for-age percentile, BMI z-scores and waist-to-height ratios, and biomarkers, i.e., metabolic, lipid and inflammation indices, with the 2 Niños Sanos groups were analyzed using Kruskal Wallace test. The range of scores spanned a narrow margin (51.5 to 80.5), i.e., only 29 points of a possible 18 to 90 or 69 points; it served the analyses better to consider 2 rather than 3 groups. Significance level was set at $p \leq 0.05$ for all analyses. Statistical analyses were performed using SAS (SAS, version 9.4, SAS Institute, Cary, NC, USA).

\section{Results}

\subsection{Demographics}

Self-reported answers to the demographic questionnaire confirmed, as anticipated, that our cohort was predominantly low-income with Spanish as their first language, as shown in Table 2. All caregivers were female $(100 \%)$ and most were not employed $(71 \%)$. The majority reported earning a monthly household income of less than $\$ 2000(57 \%)$. Additionally, families enrolled in the study participated in at least one USDA assistance program, with WIC (83\%), Head Start $(80 \%)$, Medicaid $(70 \%)$ and SNAP (40\%) being reported most frequently. All parents (100\%) self-reported their and their child race/ethnicity as Hispanic/Latino. Most parents ( $81 \%)$ were born in Mexico, the majority $(79 \%)$ had been living in the US for more than 10 years and $86 \%$ reported speaking Spanish at home. Parents were $33.6 \pm 6$ years old female $(99 \%)$ married $(65 \%)$ with a majority reporting having completed some high school or receiving a high school diploma (79\%). Only $20 \%$ of the parents had a normal BMI with $80.5 \%$ having a BMI greater than 25 . All children ( $54 \%$ female) were born in the US and were on average 44.7 months old at enrollment. 
Table 2. Descriptive statistics of Niños Sanos study participants by parent, child, family and acculturation variables ( $n=206$ parent/child dyads).

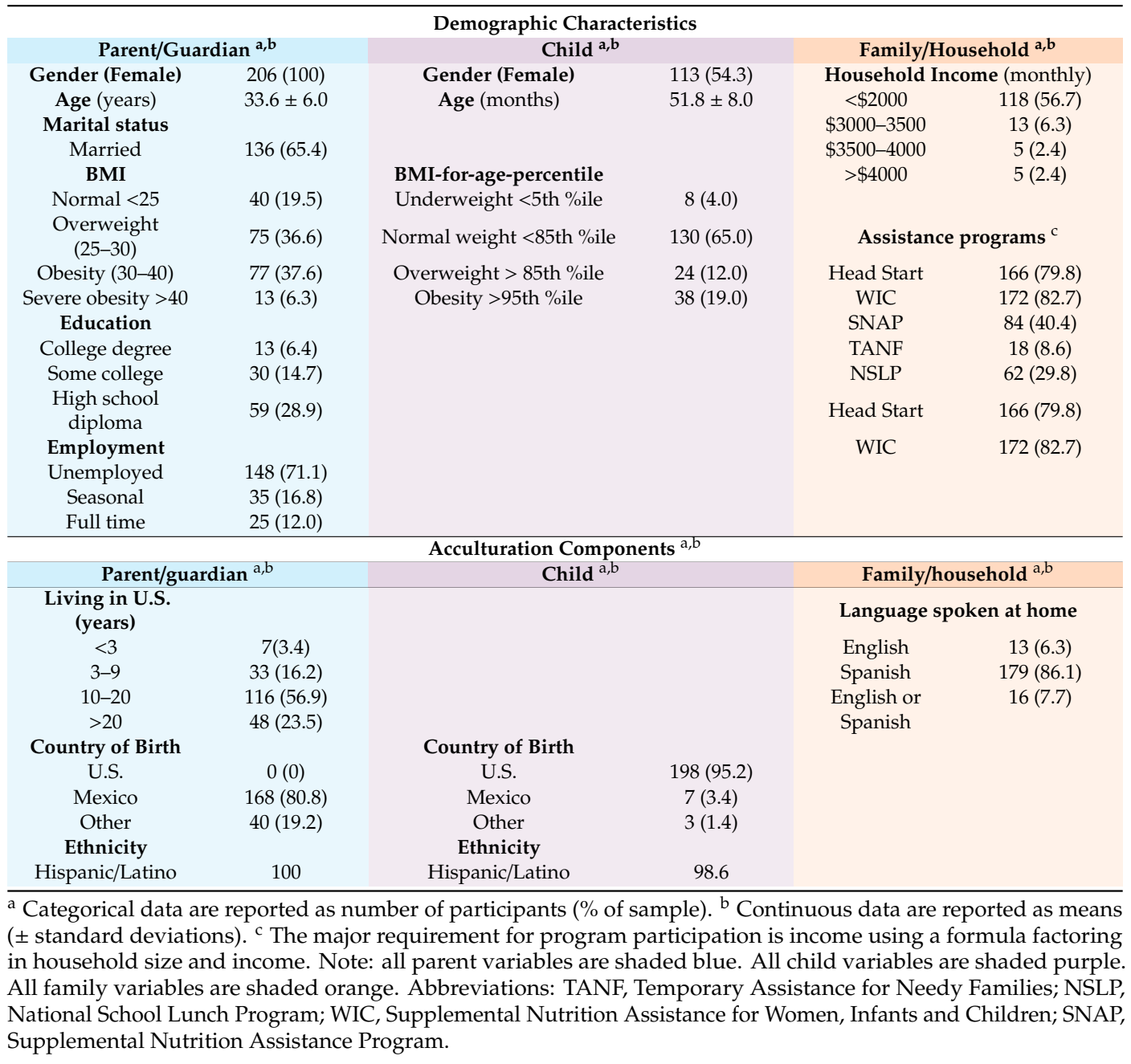

\subsection{Item Reduction for Niños Sanos}

The 18 items were selected based on their inverse association with child anthropometric boxplots; they are presented in Table 3 organized by behavioral domains or constructs. Item responses, means and standard deviations are presented with a maximum of five points representing the healthiest score. The subsequent validation analyses were conducted using this 18-item final version of Niños Sanos for a possible score ranging from 18 to 90 points. Although the lowest potential score was 18, the minimum reported score was 51.5 because few participants selected response options 1 and 2 . The maximum reported score was 80.5. Using answers from the new version of Niños Sanos with 18 items, responses were scored and results were discretized into two groups of low and high scores (51.5 to to 74.9 points; 75.0 to 80.5 points) to adjust for skewness of the data in subsequent analyses. The range of scores for the individual items was fairly narrow with most item scores falling into the response options 3 and 4 . 
Table 3. Behavioral domain and construct, item text, item visual content and means \pm SD for 18 items selected for final version of Niños Sanos assessment tool.

\begin{tabular}{|c|c|c|c|}
\hline $\begin{array}{l}\text { Behavioral Domain } \\
\text { \& Construct }\end{array}$ & Item Text & Item Visual & Response $^{a}$ \\
\hline \multicolumn{4}{|c|}{ Vegetables } \\
\hline Vegetable availability & $\begin{array}{l}\text { Compro vegetales. } \\
\text { I buy vegetables. }\end{array}$ & $\begin{array}{l}\text { Left: woman getting ready to buy } \\
\text { broccoli with her daughter. Right: bag } \\
\text { of frozen mixed vegetables, box of } \\
\text { frozen green beans, can of diced } \\
\text { tomatoes, can of corn and can of } \\
\text { mixed vegetables. }\end{array}$ & $4.2 \pm 1.0$ \\
\hline $\begin{array}{l}\text { Vegetable } \\
\text { accessibility }\end{array}$ & $\begin{array}{l}\text { Tengo vegetales listos para que } \\
\text { mi niño (a) se los coma. } \\
\text { I keep vegetables ready for } \\
\text { my child to eat. }\end{array}$ & $\begin{array}{l}\text { Left: refrigerator shelf with bowl of } \\
\text { washed cherry tomatoes, carrot and } \\
\text { celery sticks in a glass, carrot } \\
\text { sticks/celery sticks/cherry tomato in } \\
\text { snack bag. Right: child reaching for } \\
\text { vegetable snack on refrigerator shelf. }\end{array}$ & $3.2 \pm 1.3$ \\
\hline \multicolumn{4}{|c|}{ Fruit } \\
\hline Fruit intake & $\begin{array}{l}\text { Yo como frutas _ veces al dia. } \\
\text { I eat fruit___times a day. }\end{array}$ & $\begin{array}{l}\text { Left: mother biting into an apple. } \\
\text { Right: another mother eating a } \\
\text { banana. }\end{array}$ & $3.3 \pm 0.9$ \\
\hline Fruit availability & $\begin{array}{l}\text { Compro frutas. } \\
\text { I buy fruit. }\end{array}$ & $\begin{array}{c}\text { Left: mother biting into an apple. } \\
\text { Right: another mother eating a } \\
\text { banana. }\end{array}$ & $4.4 \pm 0.8$ \\
\hline \multicolumn{4}{|c|}{ Beans } \\
\hline $\begin{array}{l}\text { Dry cooked bean } \\
\text { intake }\end{array}$ & $\begin{array}{l}\text { Mi niño (a) come frijoles } \\
\text { veces por semana. } \\
\text { My child eats beans } \\
\text { times a week. }\end{array}$ & $\begin{array}{c}\text { Left: dry beans as purchased, cooked } \\
\text { dry beans in cans. Right: mother and } \\
\text { daughter who is serving prepared } \\
\text { beans. }\end{array}$ & $2.4 \pm 1.0$ \\
\hline \multicolumn{4}{|c|}{ Dairy } \\
\hline Milk frequency & $\begin{array}{l}\text { Mi niño(a) toma leche _ veces } \\
\text { al dia. } \\
\text { My child drinks milk } \\
\text { _times a day. }\end{array}$ & $\begin{array}{l}\text { Left: parent pouring milk on cereal. } \\
\text { Center: Boy drinking milk in glass } \\
\text { with snack/meal. Right: boy drinking } \\
\text { chocolate milk via a straw. }\end{array}$ & $3.3 \pm 0.8$ \\
\hline Milk frequency & $\begin{array}{l}\text { Yo tomo leche_ _ veces al dia. } \\
\text { I drink milk__ times a day. }\end{array}$ & $\begin{array}{c}\text { Left: mother drinking milk from a } \\
\text { glass. Right: another mother drinking } \\
\text { milk from a glass. }\end{array}$ & $2.3 \pm 0.8$ \\
\hline \multicolumn{4}{|c|}{ Whole Grains } \\
\hline Milk with cereal & $\begin{array}{l}\text { A mi nino(a) le gusta comer } \\
\text { cereal en el desayuno. } \\
\text { My child enjoys cereal for } \\
\text { breakfast. }\end{array}$ & $\begin{array}{l}\text { Child with cereal and empty glass of } \\
\text { milk. }\end{array}$ & $3.0 \pm 1.2$ \\
\hline \multicolumn{4}{|c|}{ Sugar Sweetened Beverages } \\
\hline Soda frequency & $\begin{array}{l}\text { Mi niño(a) toma sodas _ veces } \\
\text { al dia. } \\
\text { My child drinks soda } \\
\text { times a day. }\end{array}$ & $\begin{array}{l}\text { Left: girl drinking Mexican soda from } \\
\text { a bottle. } \\
\text { Right: selection of carbonated } \\
\text { beverages in cans, bottles and paper } \\
\text { cup from Mexico and U.S. }\end{array}$ & $4.7 \pm 0.4$ \\
\hline $\begin{array}{l}\text { Sports drinks, punch } \\
\text { frequency }\end{array}$ & $\begin{array}{c}\text { Mi niño(a) toma bebidas } \\
\text { deportivas o endulzadas } \\
\text { veces al día. } \\
\text { My child drinks sport drinks } \\
\text { or sugared drinks__ times } \\
\text { a day. }\end{array}$ & $\begin{array}{l}\text { Left: boy drinking Kool-Aid@ from } \\
\text { disposible pouch. Right: SunnyD@, } \\
\text { Hawaiian Punch@, Propel Fitness } \\
\text { Water@, Gatorade(C, Kool-Aid@C. }\end{array}$ & $4.5 \pm 0.6$ \\
\hline \multicolumn{4}{|c|}{ Fat/Saturated Fat } \\
\hline Energy density & $\begin{array}{c}\text { Mi niño(a) come comida rápida } \\
\text { — veces a la semana. } \\
\text { My child eats fast food } \\
\text { times a week. }\end{array}$ & $\begin{array}{l}\text { Child eating hamburger from fast } \\
\text { food outlet. Also shown are French } \\
\text { fries and soda in paper cup with straw } \\
\text { from a Happy Meal box. }\end{array}$ & $4.4 \pm 0.4$ \\
\hline $\begin{array}{l}\text { Fat, energy density, } \\
\text { saturated fat }\end{array}$ & $\begin{array}{l}\text { Le quito la grasa a la carne } \\
\text { antes de comerla. } \\
\text { I trim fat before eating. }\end{array}$ & $\begin{array}{l}\text { Parent's hand with knife trimming fat } \\
\text { from raw meat on cutting board. } \\
\text { Parent's hand with fork and knife } \\
\text { trimming fat from cooked meat as } \\
\text { served on dinner plate. }\end{array}$ & $4.3 \pm 1.1$ \\
\hline
\end{tabular}


Table 3. Cont.

\begin{tabular}{|c|c|c|c|}
\hline $\begin{array}{l}\text { Behavioral Domain } \\
\text { \& Construct }\end{array}$ & Item Text & Item Visual & Response $^{a}$ \\
\hline \multicolumn{4}{|c|}{ Snack Foods } \\
\hline $\begin{array}{l}\text { Energy dense foods } \\
\text { for snack }\end{array}$ & $\begin{array}{c}\text { Mi nino(a) come snacks como } \\
\text { papitas (chips), galletas y } \\
\text { dulces. } \\
\text { My child eats snack foods } \\
\text { like cookies, chips and } \\
\text { candy. }\end{array}$ & $\begin{array}{l}\text { Left: boy eating cookie. } \\
\text { Center: girl eating Mexican pastry } \\
\text { Right: girl eating chips. }\end{array}$ & $4.0 \pm 0.7$ \\
\hline \multicolumn{4}{|c|}{ Eating Out } \\
\hline Energy density & $\begin{array}{c}\text { Nosotros comemos fuera } \\
\text { _veces a la semana. } \\
\text { We eat out__times a week. }\end{array}$ & $\begin{array}{l}\text { Two parents with young child sitting } \\
\text { at table in restaurant eating burritos } \\
\text { and soda. }\end{array}$ & $4.1 \pm 0.8$ \\
\hline \multicolumn{4}{|c|}{ Cooking at Home } \\
\hline Energy density & $\begin{array}{l}\text { Preparo las comidas para mi } \\
\text { niño }(a) \text {. } \\
\text { I cook my child's dinner } \\
\text { from scratch. }\end{array}$ & $\begin{array}{l}\text { Parent at stove cooking meat in skillet } \\
\text { with young child watching. }\end{array}$ & $4.6 \pm 0.7$ \\
\hline \multicolumn{4}{|c|}{ Screen Time } \\
\hline Television & $\begin{array}{c}\text { Mi niño(a) mira la televisión } \\
\text { _horas al dia. } \\
\text { My child watches TV } \\
\text { hours a day. }\end{array}$ & $\begin{array}{c}\text { Girl watching TV in living room/front } \\
\text { room. }\end{array}$ & $3.7 \pm 0.6$ \\
\hline \multicolumn{4}{|c|}{ Physical Activity } \\
\hline $\begin{array}{l}\text { Play, } \\
\text { sedentary time }\end{array}$ & $\begin{array}{c}\text { A mi niño(a) le gusta jugar en } \\
\text { lugar de ver televisión. } \\
\text { My child likes playing } \\
\text { instead of watching TV. }\end{array}$ & Girl playing with toy in her bedroom. & $3.4 \pm 1.1$ \\
\hline \multicolumn{4}{|c|}{ Sleep } \\
\hline Bedtime & $\begin{array}{c}\text { Mi niño(a) se acuesta alrededor } \\
\text { de las _ PM. } \\
\text { My child goes to bed around } \\
\text { p.m. }\end{array}$ & $\begin{array}{l}\text { Young girl asleep in her bed in child's } \\
\text { dark bedroom. }\end{array}$ & $3.0 \pm 0.8$ \\
\hline
\end{tabular}

The constructs in the 18-item version included fruit availability and intake, vegetable availability and accessibility, eating dry cooked beans, milk intake, wholegrain intake, sugar sweetened beverages frequency, fast food frequency, trimming fat before eating, energy dense snacking, eating out, cooking from scratch, sedentary time, play vs. watching TV and sleep. The final version with 18 items is shown in Figure 2 [61].

\subsection{Niños Sanos and Child Anthropometry}

A significant inverse relationship between the child's 18-item Niños Sanos scores and BMI-for-age percentiles $(p=0.02)$ using Kruskal-Wallis is shown in Figure 3 and Table 4 . The higher the child's Niños Sanos score, i.e., healthier obesity prevention behaviors, the lower the child's BMI-for-age percentile. Due to the skewness of the data, medians with interquartile range (IQR) instead of means with standard deviations are presented to summarize subgroup results (Table 4). Analysis using the child BMI z-scores, instead of BMI-for-age percentile, and Niños Sanos scores yielded the same inverse association with children in the high Niños Sanos scoring group having significantly lower BMI z-score than the children in the low scoring group ( $p=0.03$ ), also shown Table 4 . In addition, high scores on the Niños Sanos were also predictive of lower waist-to-height ratios in children $(p=0.05)$ as shown in Figure 3 and Table 4. We repeated the analysis using analysis of variance; similar statistical results were found. 


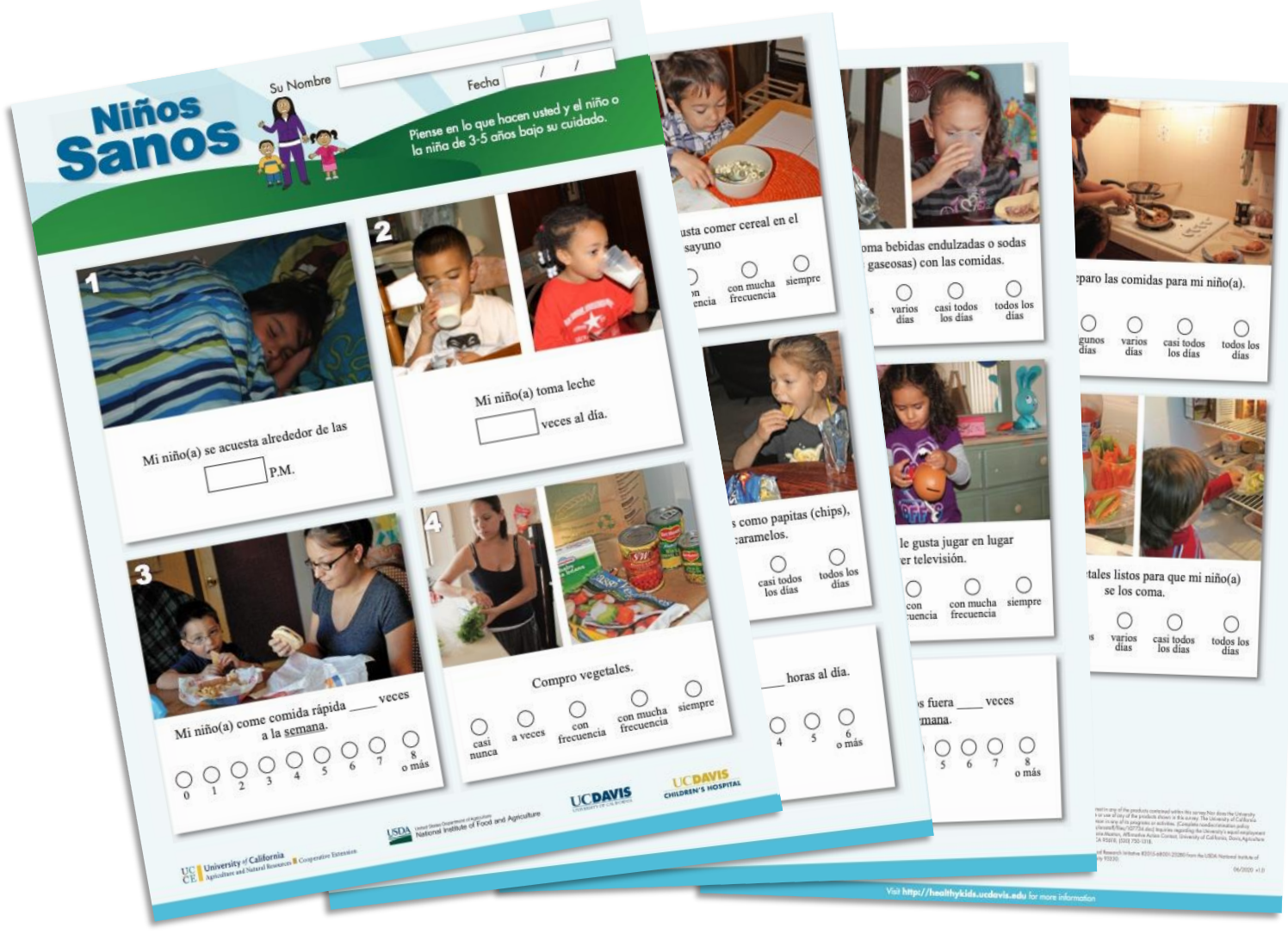

Figure 2. Niños Sanos Obesity Risk Assessment, final version with 18 items, tailored to Spanish speaking immigrant parents of $2-5$ year old children. Printed in color on one 11 by 17 -inch paper, folded in booklet format.

BMI-for-age percentiles

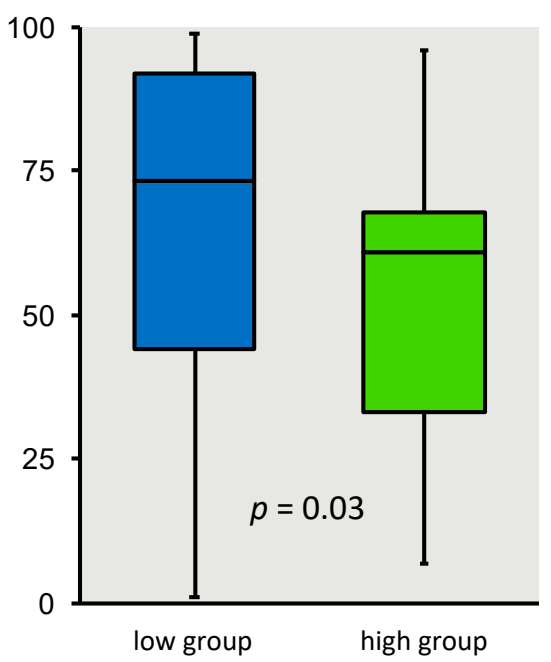

Waist-to-height ratios

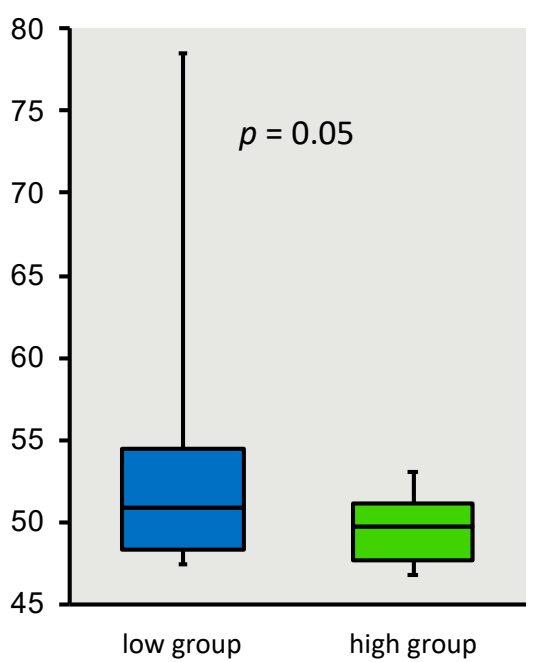

Figure 3. Child BMI-for-age percentile and waist-to-height ratios stratified by Niños Sanos groups of low and high scores. Answers on Niños Sanos, final version with 18 items, were scored and discretized into 2 groups of low and high scores ( 51.5 to 74.9 points; 75.0 to 80.5 points). Waist-to-height ratio was calculated as $100 \times$ waist $(\mathrm{cm}) /$ height $(\mathrm{cm})$. 
Table 4. Child anthropometric and blood biomarkers by index (metabolic, lipid and anti-inflammatory) stratified by low and high scores for Niños Sanos participants.

\begin{tabular}{|c|c|c|c|c|c|c|c|c|c|c|c|}
\hline & \multicolumn{10}{|c|}{ Niños Sanos } & \multirow{3}{*}{$p$-Value ${ }^{\text {a }}$} \\
\hline & \multicolumn{5}{|c|}{ Low Scoring Children } & \multicolumn{5}{|c|}{ High Scoring Children } & \\
\hline & $n$ & Median & IQR & Q1 & Q3 & $n$ & Median & IQR & Q1 & Q3 & \\
\hline \multicolumn{12}{|l|}{ Anthropometric } \\
\hline BMI percentiles-for-age & 176 & 73.50 & 48.00 & 44.00 & 92.00 & 20 & 61.00 & 35.00 & 33.00 & 68.00 & 0.024 \\
\hline BMI Z-scores & 176 & 0.65 & 1.51 & -0.12 & 1.39 & 20 & 0.29 & 1.01 & -0.45 & 0.56 & 0.028 \\
\hline Waist-to-height ratios & 176 & 50.85 & 6.08 & 48.35 & 54.43 & 20 & 49.65 & 3.45 & 47.71 & 51.16 & 0.053 \\
\hline \multicolumn{12}{|l|}{ Metabolic } \\
\hline Metabolic index & 141 & 307.07 & 166.86 & 237.11 & 403.96 & 18 & 281.08 & 145.27 & 180.90 & 326.17 & 0.028 \\
\hline Lipid index & 149 & 263.96 & 152.66 & 195.27 & 347.93 & 18 & 219.23 & 121.89 & 150.30 & 272.19 & 0.050 \\
\hline Anti-inflammatory index & 140 & 258.39 & 96.25 & 206.05 & 302.31 & 18 & 277.20 & 55.83 & 253.99 & 309.82 & 0.047 \\
\hline
\end{tabular}

a. Kruskal Wallis. Bold text in left column show variable categories. Others without bold are variable sub-categories. $p$-values are shown in right-hand column in bold with light mauve shading.

\subsection{Child Biomarkers and Anthropometry}

There was a significant positive association between the metabolic and lipid biomarker indices and the underweight, normal and overweight BMI categories. In contrast, the anti-inflammatory index was inversely associated with BMI categories (Table S1).

\subsection{Niños Sanos and Child Biomarker Indices}

As hypothesized, circulating child blood levels of biomarkers grouped into metabolic and lipid indices were significantly higher in children with low Niños Sanos scores, while high scores predicted lower metabolic $(p=0.03)$ and lipid indices $(p=0.05)$. In addition, a high Niños Sanos score was associated with a higher anti-inflammatory index reflecting a more healthful status $(p=0.047)$ (Figure 4 , Table 4).

A

Metabolic Index

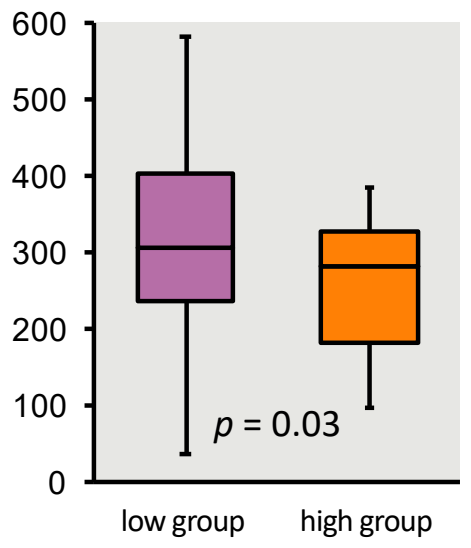

B

Lipid Index

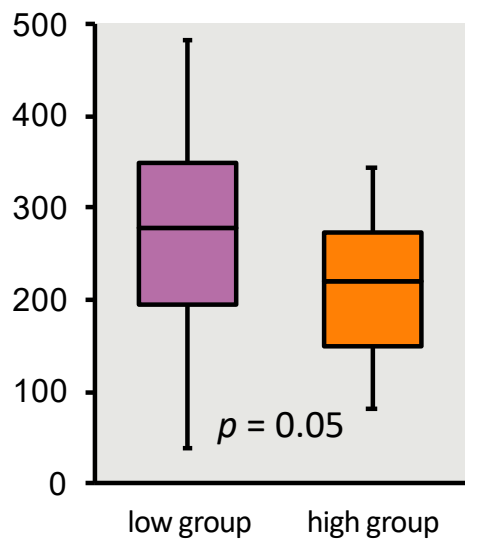

C

Anti-inflammatory Index

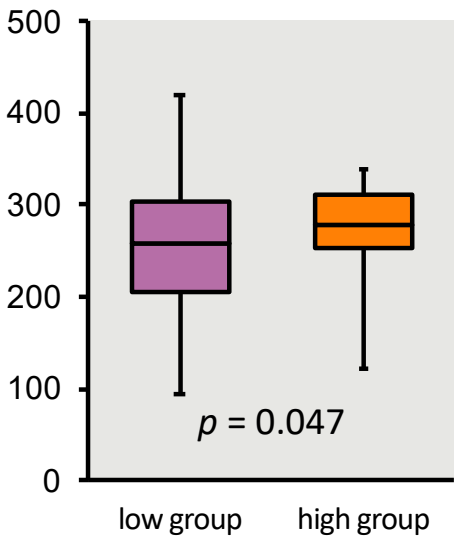

Figure 4. Child biomarker indices for metabolic (A), lipid (B) and anti-inflammatory (C) stratified by Niños Sanos groups of low and high scores. Answers on Niños Sanos, final version with 18 items, were scored and discretized into 2 groups of low and high scores (51.5 to 74.9 points; 75.0 to 80.5 points). Metabolic index (A) composed of glucose, insulin, leptin, leptin:adiponectin. Lipid index (B) composed of triglycerides, high density lipoprotein (HDL) cholesterol, low density lipoprotein cholesterol, cholesterol:HDL cholesterol. Anti-inflammatory index (C) composed of Interleukin 10, adiponectin and IGFBP-1 insulin growth factor binding protein, resistin and C-reactive protein.

\section{Discussion}

This research paper describes the quantitative research to establish criterion validity of Niños Sanos using objective parameters collected from young children, 3-5 years old, of Spanish-speaking 
immigrant parents, including those with limited written Spanish literacy. The relationship was statistically significant between Niños Sanos scores and three anthropometric measures that included BMI-for-age percentile, BMI Z-scores and waist-to-height ratios and three blood biomarker indices of obesity that included a metabolic index, lipid index and anti-inflammatory index as shown in Table 4 and Figure 3. Children in the high scoring group for Niños Sanos, i.e., the healthier scores, had lower BMI-for-age percentile, BMI z-scores and waist-to-height ratios and significant healthful metabolic, lipid and inflammatory profiles. Conversely, children with lower Niños Sanos scores showed compromised health status. The results suggest that a tool like Niños Sanos is useful to identify children of Spanish-speaking immigrant families who are at risk of impaired weight and metabolic outcomes based on the environment and behaviors practiced at home. Combining these metabolic, lipid and inflammatory indices with the results for BMI-for-age percentiles, BMI z-scores and waist-to-height ratios creates a broad picture of the child's health status. Moreover, Niños Sanos is related to all these variables indicating that criterion validation is established for the tool. Those children with higher scores have a better health profile both metabolically and anthropometrically than children in the lower scoring group.

\subsection{Anthropometric and Blood Biomarkers in Children}

Children and particularly children of Mexican descent may be at risk for metabolic complications and anthropometric parameters may not be as sensitive to the changes in visceral fat accumulation as circulating levels of adipokines and other metabolic parameters $[9,62]$. The inclusion of biomarkers may provide additional means to identify children with obesogenic family environments. Individually, circulating levels of biomarkers measured in our study compare reasonably to reference values published in the literature (Supplemental Table S1). As minimal biomarker research has been undertaken with young children, it was not clear to us at what age biomarkers of obesity could be used to validate an obesity prevention risk assessment tool. However, it would appear from our data that ages $3-5$ years is not too young.

In our study, children with high BMI-for-age percentiles show an unfavorable blood lipid profile. Longitudinal studies have shown that children with high BMI have increased risk of cardiovascular disease in adulthood [63]. Studies with large cohorts of Hispanic children indicate that pre and post pubertal children with overweight or obesity have significantly higher levels of TG and LDL-C and lower circulating HDL-C than normal weight peers [64,65]. This is relevant for children of Mexican descent who because of genetic predisposition have been found to be at a greater risk for early onset of adverse health complications [62]. It is a concerning observation as dyslipidemia leading to atherosclerosis may begin in childhood for children with obesity [24].

Although we did not screen specifically for the prevalence of obesity in our child participants, it was higher at $19 \%$ than the US obesity rates for 2-5 year olds at $14 \%$. Moreover, these overweight and obese children exhibited high HOMA-IR and leptin to adiponectin ratio, exceeding the published cut off levels for children that age. As observed in adults with obesity, our data as well as that of other researchers indicate that elevated insulin or insulin resistance is not uncommon in Hispanics children with obesity $[54,66]$. In pre-pubertal children with obesity, low levels of circulating IGFBP1 and adiponectin are strong predictors of insulin resistance and metabolic complications $[54,67,68]$. Both biomarkers were lower in children with overweight and obesity in our study, while leptin levels were elevated. These 2 conditions (high leptin and low adiponectin) appear to be important markers of body fat and of comorbidity risk in children $[12,16,66]$. Overall, our results support that these selected biomarkers were sensitive to obesogenic behaviors and likely reflect body visceral fat accumulation. Thus, these biomarkers were useful for the validation of Niños Sanos.

\subsection{Advancing Obesity Risk Assessment}

Advancing the science of obesity risk assessment requires integrated approaches that deploy multiple types of validation and determine alignment with objective measures [69]. Public health 
experts have called upon the behavioral sciences to consider a more integrated approach to better understand how obesogenic behaviors interact. Instead of assessing one behavior in isolation, it is recommended to measure multiple co-dependent obesogenic behaviors simultaneously [69]. Exploring the integration of obesity related behaviors like the time children spend active, sedentary and sleeping and the synergy on childhood obesity is regarded as a paradigm shift from current practice. The present study is an example of a validation research using objective standards, such as BMI and blood biomarkers, to determine the usefulness of a self-report tool that encompasses the assessment of multiple behaviors-various dietary components, physical activity, sleep and screen time-to identify children at risk of obesity and related diseases. In addition, validation studies have traditionally focused on validating obesity-related self-report behavioral tools using other subjective self-report measures, such as the $24 \mathrm{~h}$ diet recall or food frequency questionnaire [70]. Another paradigm shift has occurred over 20 years, emphasizing the need for objective assessments of obesogenic behaviors to validate short self-report behavioral tools, in addition to the more traditional self-report measures. This was accomplished through the introduction of biologic objective measures [70], such as blood values to assess chronic low-grade inflammation [40], serum carotenoids to validate fruit and vegetable intakes [42], body mass index and other anthropometric markers [71], videotaping family meals to measure parenting practices [72], digital photography to measure dietary intake [73] and actigraphy devices to measure physical activity, sedentary behavior and sleep. The emphasis in all these methods are objective measurements to support or replace the more traditional parent-report methods. In addition to objective measurements for validation, there is more interest in incorporating multiple approaches to get a more complete picture of the validation process [69]. Each type of validation provides somewhat different information and adds to this total validation picture. Likewise, each type of reliability assessment provides different information. Reliability results for Niños Sanos will be reported elsewhere.

\subsection{Comparison to Other Validation Studies for This Audience}

For comparison, our previous [36,37] and more recent reviews of the literature found no validation studies supporting obesity prevention tools for low-income, Spanish-speaking families with young children. However, there were two similar tools reported in the literature targeting English-speaking families with young children. The 21-item Family Nutrition and Physical Activity (FNPA) screening tool for English-speaking families with children 6-12 years was designed for school and medical clinic settings and was extensively validated with objective measures including anthropometric and blood biomarkers [74,75] and translated into Spanish. A second tool was cognitively tested with Spanish speakers to establish face validity for use with EFNEP evaluation, and by comparing it to other self-report behavioral assessments for diet, lifestyle and parenting [76]. Niños Sanos is the only pediatric obesity risk assessment tool designed specifically for Spanish-speaking parents and rigorously validated with objective measures, including anthropometry and blood biomarkers. Given the high prevalence of overweight and obesity among the Hispanic population in the U.S., a tool such as this was long overdue.

\subsection{Beyond Translation}

The original 45-item Niños Sanos was tested to ensure conceptual equivalence with the original 45-item English version Healthy Kids. In both tools, selection of items for their respective final versions was driven by the relationship with anthropometric markers of childhood obesity. Nonetheless, the set of items identified to be criterion-relevant differed substantially between both tools, with only eight overlapping items. The vegetable domain, for instance, had nine items in both 45 -item versions. Five of the nine items performed well with BMI for English speakers, thus were included in the 19-item risk assessment version of the tool. In contrast, only two of the nine items were associated with anthropometric measures among Spanish speakers, and only one of them performed well with both audiences - the vegetable availability item. Vegetable accessibility was found relevant for Spanish 
speakers, while vegetable modelling at mealtime, vegetable snacks and vegetable variety items were important for the English but not Spanish speakers. These findings are clear evidence of the need to apply the same level of exhaustiveness and rigor to the validation of tools intended for culturally and linguistically specific audiences. While useful to establishing feasibility of reach, forward and back translations are always insufficient to ensure the content relevance and accuracy of a tool, including its usefulness at identifying those at risk of malnutrition and related conditions [77,78]. Practitioners for community nutrition education programs with mixed audiences may find using two different tools for program evaluation impractical. However, matters of convenience should be considered against the fact that data-driven valid tools are essential for accurate and meaningful evaluation.

\subsection{Comparison to Other Biomarker Literature}

Using the Framework (Figure 1), these data show that the Niños Sanos tool is valid to use for risk assessment in Hispanic families with 2-5 year-old children. To support the strength and direction of our findings, biomarkers and Niños Sanos tool, we examined other biomarker studies, some of which were interventions. Children with overweight or obesity have low circulating interleukin-10 concentrations, also found by Chang et al. [18]. In pre-pubertal children with obesity, low circulating IGFBP-1 is a strong predictor of insulin resistance and metabolic complications [67].

\subsection{Using Niños Sanos}

The Niños Sanos behavioral assessment for Spanish-speaking immigrant families has culturally appropriate color photographs demonstrating each behavior to minimize cognitive load. This assessment format is optimal for audiences with limited literacy and for those immigrating from Spanish-speaking countries and whose English proficiency is limited [35]. Niños Sanos takes substantially less time for participants to complete than $24 \mathrm{~h}$ diet recalls and does not need a professional for data collection and interpretation. Tailored goals can be generated from the Niños Sanos results available at http://healthykids.ucdavis.edu/ to assist parents with goal setting during an intervention or counseling session for families with children most at risk for metabolic disturbances and excess weight gain $[79,80]$. This tool could serve other functions as well. First, it could be used in research studies targeting low-income Spanish-speaking audiences. Niños Sanos could also serve as an evaluation to assess program or intervention impact. Lastly, medical providers could benefit from a risk assessment tool during well-child visits as recommended by the American Academy of Pediatrics $[4-6,81,82]$.

\subsection{Limitations and Strengths}

This study had multiple strengths including use of objective robust analytical approaches to establish validity of Niños Sanos (Figure 1) not subject to self-report bias, i.e., direct measurement of height, weight and waist by physical examination and collection of blood for measurement of metabolic, lipid and anti-inflammatory biomarker values; these markers provide confidence in the estimates and outcomes generated by this research [70]. Another strength is the sample of low-income Hispanic children at high risk for obesity.

At the same time, a number of limitations should be noted. The biomarker reference values available from the literature and cited in the Supplemental Table S1, were based on data available for non-Hispanic white children, not other racial/ethnic groups. Although the external validity of these findings to other Spanish-speaking immigrant audiences is unknown, the methods applied to the development of the tool are consistent with theories of visual information processing [83] and cross-cultural adaptation principles [84], with efforts to reduce client cognitive load for those federal program participants with a broad range of literacy skills [85]. As parents volunteered to participate and were not randomly drawn from the larger low-income Spanish-speaking WIC and Head Start populations, the variability of their responses may be smaller compared to that of the general limited-resource target population. Consequently, selection bias must be considered as a 
threat to external validity [86]. Only a small portion of the children in the study scored high in the Niños Sanos tool (i.e., $n=20$ ). Despite the impact on the statistical power this could have posed, the differences between the two groups were statistically significant for BMI and z-scores indicating that the differences were real. Similarly, for the biomarker analyses, even as the sample size was constrained by the number of participants with a blood sample sufficient in quantity for each type of biomarker analysis, we were able to detect statistical significance on the metabolic, lipid and anti-inflammatory indices. The boxplot for each of the three biomarker indices (Figure 3) indicates children's values moving in predicted directions.

\section{Conclusions and Implications}

To our knowledge, this is the first study establishing criterion validity for a pediatric obesity assessment tool targeting Spanish-speaking immigrant families with young children. Niños Sanos has potential as a rapid and easy-to-administer parent assessment of the young child's risk of overweight or obesity in a community education or medical clinic setting, as an evaluation assessment of a corresponding education intervention or in a research setting. The validation results show statistically significant relationships between Niños Sanos and BMI-for-age percentiles, BMI z-scores, waist-to-height ratio, and with metabolic, lipid and inflammatory profiles.

Implications of this Niños Sanos validation study include contributing to the body of literature on the use of objective biometric measures for robust validation of self-report behavioral measures and to expand their value to risk detection. Researchers can use the study to encourage the use of blood biomarkers with young children for future validation research. The study also provides evidence that a tool intended to be used with audiences culturally different from which it was originally created requires thorough validation with objective indicators to ensure behaviors are accurately measured for plausible risk detection. Lastly, to further address the complexity of childhood obesity risk, a parenting practices assessment, My Child at Mealtime and its culturally adapted version, Mi Niño a la Hora de Comer validated with Spanish-speaking parents, developed by the same research group, is intended for use in tandem with Niños Sanos [71,72,87].

Supplementary Materials: The following are available online at http://www.mdpi.com/2072-6643/12/11/3582/s1, Figure S1: Flow diagram of initial recruits and subsequent dropouts of parent/child dyads at each stage of data collection for the Niños Sanos validation study, Table S1: Biomarkers (metabolic, lipid and anti-inflammation index) and range values, stratified by children BMI-for-age percentiles (ranks) for Niños Sanos study participants.

Author Contributions: M.S.T. was the principal investigator responsible for the grant, conceptualized the study, participated in discussions of data analysis and interpretation and wrote drafts of the manuscript. M.K.S. was co-PI on the grant, conceptualized the study, provided her expertise on data entry and management, participated in discussions of data analysis and interpretation and reviewed drafts. L.L. supervised data entry and management, conducted literature searches on biomarkers, conducted statistical analyses, participated in discussions of data interpretation including biomarker results and co-wrote the manuscript drafts. C.D. supervised the statistical analyses, participated in discussions of data analysis and interpretation and wrote statistical methods section. L.K.D.R. conducted cultural adaptation, including translation and cognitive interviews, participated in discussions of data analysis and interpretation and writing of manuscript drafts. D.M.S. was a collaborator on the grant, conceptualized the study and provided substantial intellectual input in the selection of the biomarkers. N.L.K. participated in biomarker selection process, served as an expert resource for biomarker analyses and participated in discussions of data interpretation. L.O. was a co-PI on grant, conceptualized the study and served as an expert on parenting issues. All authors have read and agreed to the published version of the manuscript.

Funding: This research was funded by the National Institute of Food and Agriculture, U.S. Department of Agriculture, under award number \#2015-68001-23280. Dr. Keim was supported by USDA-ARS, CRIS projects 2032-51530-022-00D and 2032-51530-025-00D. The USDA is an equal opportunity employer and provider.

Acknowledgments: The authors thank Ellen Bonnel for establishing and executing the protocol for blood collection and processing; Misty L. Reed for the Niños Sanos design; SETA Head Start and WIC, Sacramento; Maria Espinoza, Gloria Zavala and Lizania Romero for data collection and data entering. Larissa Leavens and Christine Davidson for staff training and data processing; and Gertrud Schuster for the biomarker analyses under the supervision of Leslie Woodhouse. 
Conflicts of Interest: The authors declare no conflict of interest. The funders had no role in the design of the study; in the collection, analyses, or interpretation of data; in the writing of the manuscript, or in the decision to publish the results.

\section{References}

1. Skinner, A.C.; Ravanbakht, S.N.; Skelton, J.A.; Perrin, E.M.; Armstrong, S.C. Prevalence of Obesity and Severe Obesity in US Children, 1999-2016. Pediatrics 2018, 141. [CrossRef] [PubMed]

2. Ogden, C.L.; Fryar, C.D.; Hales, C.M.; Carroll, M.D.; Aoki, Y.; Freedman, D.S. Differences in Obesity Prevalence by Demographics and Urbanization in US Children and Adolescents, 2013-2016. JAMA 2018, 319, 2410-2418. [CrossRef] [PubMed]

3. Ward, Z.J.; Long, M.W.; Resch, S.C.; Giles, C.M.; Cradock, A.L.; Gortmaker, S.L. Simulation of Growth Trajectories of Childhood Obesity into Adulthood. N. Engl. J. Med. 2017, 377, 2145-2153. [CrossRef] [PubMed]

4. Institute of Medicine (US). Committee on Prevention of Obesity in Children and Youth. In Preventing Childhood Obesity: Health in the Balance; Koplan, J.P., Liverman, C.T., Kraak, V.I., Eds.; The National Academies Collection: Reports funded by National Institutes of Health; National Academies Press (US): Washington, DC, USA, 2005; ISBN 978-0-309-09196-1.

5. Krebs, N.F.; Jacobson, M.S. American Academy of Pediatrics Committee on Nutrition Prevention of pediatric overweight and obesity. Pediatrics 2003, 112, 424-430. [CrossRef] [PubMed]

6. Yanovski, S.Z.; Yanovski, J.A. Viewpoint: Toward Precision Approaches for the Prevention and Treatment of Obesity. JAMA 2018, 319, 223-224. [CrossRef]

7. Mann, J.P.; Anstee, Q.M. PNPLA3 and obesity: A synergistic relationship in NAFLD. Nat. Rev. Gastroenterol. Hepatol. 2017, 14, 506-507. [CrossRef]

8. Davis, J.N.; Lê, K.A.; Walker, R.W.; Vikman, S.; Spruijt-Metz, D.; Weigensberg, M.J.; Allayee, H.; Goran, M.I. Increased hepatic fat in overweight Hispanic youth influenced by interaction between genetic variation in PNPLA3 and high dietary carbohydrate and sugar consumption. Am. J. Clin. Nutr. 2010, 92, 1522-1527. [CrossRef]

9. Leoni, M.C.; Valsecchi, C.; Mantelli, M.; Marastoni, L.; Tinelli, C.; Marchi, A.; Castellazzi, A. Impact of child obesity on adipose tissue physiology: Assessment of adipocytokines and inflammatory cytokines as biomarkers of obesity. Pediatr. Rep. 2010, 2. [CrossRef]

10. Körner, A.; Kiess, W.; Landgraf, K. White Adipose Tissue Accumulation and Dysfunction in Children with Obesity. In Pediatric Obesity: Etiology, Pathogenesis and Treatment; Freemark, M.S., Ed.; Springer International Publishing: Cham, Germany, 2018; pp. 95-115. ISBN 978-3-319-68192-4.

11. Aguilar-Morales, I.; Colin-Ramirez, E.; Rivera-Mancía, S.; Vallejo, M.; Vázquez-Antona, C. Performance of Waist-To-Height Ratio, Waist Circumference, and Body Mass Index in Discriminating Cardio-Metabolic Risk Factors in a Sample of School-Aged Mexican Children. Nutrients 2018, 10, 1850. [CrossRef]

12. Frithioff-Bøjsøe, C.; Lund, M.A.V.; Lausten-Thomsen, U.; Hedley, P.L.; Pedersen, O.; Christiansen, M.; Baker, J.L.; Hansen, T.; Holm, J.-C. Leptin, adiponectin, and their ratio as markers of insulin resistance and cardiometabolic risk in childhood obesity. Pediatr. Diabetes 2020, 21, 194-202. [CrossRef]

13. Jung, M.K.; Yoo, E.-G. Hypertriglyceridemia in Obese Children and Adolescents. J. Obes. Metab. Syndr. 2018, 27, 143-149. [CrossRef] [PubMed]

14. Gonzalez-Gil, A.M.; Peschard-Franco, M.; Castillo, E.C.; Gutierrez-DelBosque, G.; Treviño, V.; Silva-Platas, C.; Perez-Villarreal, L.; Garcia-Rivas, G.; Elizondo-Montemayor, L. Myokine-adipokine cross-talk: Potential mechanisms for the association between plasma irisin and adipokines and cardiometabolic risk factors in Mexican children with obesity and the metabolic syndrome. Diabetol. Metab. Syndr. 2019, 11, 63. [CrossRef] [PubMed]

15. Orlando, A.; Nava, E.; Giussani, M.; Genovesi, S. Adiponectin and Cardiovascular Risk. From Pathophysiology to Clinic: Focus on Children and Adolescents. Int. J. Mol. Sci. 2019, 20, 3228. [CrossRef] [PubMed]

16. Brand, C.; Gaya, A.C.A.; Dias, A.F.; Agostinis-Sobrinho, C.; Farinha, J.B.; Boeno, F.P.; Mota, J.; de Oliveira, A.R.; Gaya, A.R. Relationship between insulin resistance and adipocytokines: The mediator role of adiposity in children. Ann. Hum. Biol. 2020, 47, 244-249. [CrossRef] [PubMed] 
17. Tripathi, D.; Kant, S.; Pandey, S.; Ehtesham, N.Z. Resistin in metabolism, inflammation, and disease. FEBS J. 2020, 287, 3141-3149. [CrossRef]

18. Chang, J.-S.; Bai, C.-H.; Huang, Z.-C.; Owaga, E.; Chao, K.-C.; Chang, C.-C.; Chiou, H.-Y. Interleukin 10 and clustering of metabolic syndrome components in pediatrics. Eur. J. Clin. Investig. 2014, 44, 384-394. [CrossRef]

19. Flores-Ramírez, A.G.; Ibarra-Reynoso, L.D.R.; López-Lemus, H.L.; Olvera-Juárez, M.; Luevano-Contreras, C.; Garay-Sevilla, M.E. Insulin-like growth factor binding protein-1, non-alcoholic fatty liver disease, and its relationship with fructose consumption in children with obesity. Rev. Investig. Clin. 2019, 71, 339-348. [CrossRef]

20. Mattos, R.T.; Medeiros, N.I.; Menezes, C.A.; Fares, R.C.G.; Franco, E.P.; Dutra, W.O.; Rios-Santos, F.; Correa-Oliveira, R.; Gomes, J.A.S. Chronic Low-Grade Inflammation in Childhood Obesity Is Associated with Decreased IL-10 Expression by Monocyte Subsets. PLoS ONE 2016, 11, e0168610. [CrossRef]

21. Medeiros, N.I.; Mattos, R.T.; Menezes, C.A.; Fares, R.C.G.; Talvani, A.; Dutra, W.O.; Rios-Santos, F.; Correa-Oliveira, R.; Gomes, J.A.S. IL-10 and TGF- $\beta$ unbalanced levels in neutrophils contribute to increase inflammatory cytokine expression in childhood obesity. Eur. J. Nutr. 2018, 57, 2421-2430. [CrossRef]

22. Barkin, S.; Rao, Y.; Smith, P.; Po'e, E. A Novel Approach to the Study of Pediatric Obesity: A Biomarker Model. Pediatr. Ann. 2012, 41, 250-256. [CrossRef]

23. Rowicka, G.; Dylag, H.; Chełchowska, M.; Weker, H.; Ambroszkiewicz, J. Serum Calprotectin and Chemerin Concentrations as Markers of Low-Grade Inflammation in Prepubertal Children with Obesity. Int. J. Environ. Res. Public Health 2020, 17, 7575. [CrossRef] [PubMed]

24. Genovesi, S.; Parati, G. Cardiovascular Risk in Children: Focus on Pathophysiological Aspects. Int. J. Mol. Sci. 2020, 21, 6612. [CrossRef] [PubMed]

25. Sahoo, K.; Sahoo, B.; Choudhury, A.K.; Sofi, N.Y.; Kumar, R.; Bhadoria, A.S. Childhood obesity: Causes and consequences. J. Fam. Med. Prim. Care 2015, 4, 187-192. [CrossRef]

26. Anzman-Frasca, S.; Ventura, A.K.; Ehrenberg, S.; Myers, K.P. Promoting healthy food preferences from the start: A narrative review of food preference learning from the prenatal period through early childhood. Obes. Rev. 2018, 19, 576-604. [CrossRef] [PubMed]

27. Rossen, L.M.; Talih, M. Social determinants of disparities in weight among US children and adolescents. Ann. Epidemiol. 2014, 24, 705-713.e2. [CrossRef]

28. Grummon, A.H.; Taillie, L.S. Supplemental Nutrition Assistance Program participation and racial/ethnic disparities in food and beverage purchases. Public Health Nutr. 2018, 21, 3377-3385. [CrossRef]

29. Rabbitt, M.P.; Smith, M.D.; Coleman-Jensen, A. Food Security Among Hispanic Adults in the United States, 2011-2014; U.S. Department of Agriculture, Economic Research Service: Washington, DC, USA, 2016; p. 42.

30. U.S. Department of Health and Human Services Head Start Website. Available online: https://www.acf.hhs. gov/ohs (accessed on 30 September 2020).

31. U.S. Department of Agriculture. Food and Nutrition Service WIC Website. Available online: https: //www.fns.usda.gov/wic (accessed on 30 September 2020).

32. U.S. Department of Agriculture. Food and Nutrition Service SNAP-Ed Website. Available online: https: //snaped.fns.usda.gov/program-administration/guidance-and-templates (accessed on 30 September 2020).

33. U.S. Department of Agriculture. National Institute of Food and Agriculture EFNEP Website. Available online: https://nifa.usda.gov/program/expanded-food-and-nutrition-education-program-efnep (accessed on 30 September 2020).

34. Townsend, M.S. Obesity in low-income communities: Prevalence, effects, a place to begin. J. Am. Diet. Assoc. 2006, 106, 34-37. [CrossRef]

35. Townsend, M.S.; Sylva, K.; Martin, A.; Metz, D.; Wooten-Swanson, P. Improving readability of an evaluation tool for low-income clients using visual information processing theories. J. Nutr. Educ. Behav. 2008, 40, 181-186. [CrossRef]

36. Ontai, L.; Ritchie, L.; Williams, S.; Young, T.; Townsend, M.S. Guiding family-based obesity prevention efforts in low-income children in the US, Part 1: What determinants do we target? Int. J. Child. Adolesc. Health 2009, 2, 19-30.

37. Townsend, M.S.; Ontai, L.; Young, T.; Ritchie, L.; Williams, S. Guiding family-based obesity prevention efforts in low-income children in the US, Part 2: What behaviors do we measure? Int. J. Child. Adolesc. Health 2009, 2, 31-48. 
38. Townsend, M.S.; Shilts, M.K.; Ontai, L.; Leavens, L.L.; Davidson, C.; Sitnick, S. Obesity Risk for Young Children: Development and Initial Validation of an Assessment Tool for Participants of Federal Nutrition Programs. Forum Family Consum. Issues 2014, 19, 1-20.

39. Townsend, M.S.; Shilts, M.K.; Styne, D.; Lanoue, L.; Ontai, L. Healthy Kids, a 19-Item Pictorial Assessment of Child Obesity Prevention Behaviors: Eating, Physical Activity, Screen, Sleep and Parenting 2017. Available online: https://townsendlab.ucdavis.edu/evaluation-research-tools/validation-research/ (accessed on 30 September 2020).

40. Townsend, M.S.; Shilts, M.K.; Lanoue, L.; Drake, C.; Styne, D.M.; Woodhouse, L.; Ontai, L. Obesity Risk Assessment Tool among 3-5 Year Olds: Validation with Biomarkers of Low-Grade Chronic Inflammation. Child. Obes. 2020, 16, S23-S32. [CrossRef] [PubMed]

41. Townsend, M.S.; Shilts, M.K.; Styne, D.M.; Drake, C.; Lanoue, L.; Ontai, L. An Obesity Risk Assessment Tool for Young Children: Validity With BMI and Nutrient Values. J. Nutr. Educ. Behav. 2018, 50, 705-717. [CrossRef] [PubMed]

42. Townsend, M.S.; Kaiser, L.L.; Allen, L.H.; Joy, A.B.; Murphy, S.P. Selecting items for a food behavior checklist for a limited-resource audience. J. Nutr. Educ. Behav. 2003, 35, 69-77. [CrossRef]

43. Townsend, M.S.; Shilts, M.K.; Davidson, C.; Leavens, L.L. My Child's Activity \& Food Diary (Log for Recording Physical Activity, Television and Computer Times, Bedtime, Wake Up Time, School, Other Activities). 2010. Available online: https://townsendlab.ucdavis.edu/evaluation-research-tools/validation-research/ (accessed on 30 September 2020).

44. Townsend, M.S.; Shilts, M.K.; Sylva, K.; Davidson, C.; Leavens, L.L. Niños Sanos, a 45-Item Spanish Language Pictorial Assessment of Child Obesity Prevention Behaviors: Eating, Physical Activity, Screen, Sleep and Parenting. 2016. Available online: https:/townsendlab.ucdavis.edu/evaluation-research-tools/validationresearch/ (accessed on 30 September 2020).

45. Banna, J.C.; Vera Becerra, L.E.; Kaiser, L.L.; Townsend, M.S. Using qualitative methods to improve questionnaires for Spanish speakers: Assessing face validity of a food behavior checklist. J. Am. Diet. Assoc. 2010, 110, 80-90. [CrossRef] [PubMed]

46. Banna, J.C.; Townsend, M.S. Assessing factorial and convergent validity and reliability of a food behaviour checklist for Spanish-speaking participants in US Department of Agriculture nutrition education programmes. Public Health Nutr. 2011, 14, 1165-1176. [CrossRef] [PubMed]

47. Banna, J.C.; Townsend, M.S.; Sylva, K. Lista de Habitos Alimenticios (Food Behavior Checklist) for Spanish Speakers. 2010. Available online: https://townsendlab.ucdavis.edu/evaluation-research-tools/validationresearch/ (accessed on 30 September 2020).

48. Galea, S.; Riddle, M.; Kaplan, G.A. Causal thinking and complex system approaches in epidemiology. Int. J. Epidemiol. 2010, 39, 97-106. [CrossRef]

49. Engel, G.L. The clinical application of the biopsychosocial model. Am. J. Psychiatry 1980, 137, 535-544. [CrossRef]

50. U.S. Department of Agriculture. Food and Nutrition Service the Supplemental Nutrition Assistance Program Education (SNAP-Ed) Strategies and Interventions. Available online: https://snaped.fns.usda.gov/programadministration/snap-ed-toolkit-strategies-interventions (accessed on 30 September 2020).

51. U.S. Department of Health and Human Services. National Cancer Institute Automated Self-Administered 24-Hour (ASA24@) Dietary Assessment Tool. Available online: https://epi.grants.cancer.gov/asa24/ (accessed on 30 September 2020).

52. Centers for Disease Control and Prevention, N.C. for H.S. 2000 CDC Growth Charts for the United States: Methods and Development. Available online: https://www.cdc.gov/growthcharts/cdc_charts.htm (accessed on 30 September 2020).

53. Centers for Disease Control and Prevention A SAS Program for the 2000 CDC Growth Charts (ages 0 to $<20$ y). Available online: http://www.cdc.gov/nccdphp/dnpao/growthcharts/resources/sas.htm (accessed on 14 July 2014).

54. Klünder-Klünder, M.; Flores-Huerta, S.; García-Macedo, R.; Peralta-Romero, J.; Cruz, M. Adiponectin in eutrophic and obese children as a biomarker to predict metabolic syndrome and each of its components. BMC Public Health 2013, 13, 88. [CrossRef] 
55. Zhang, M.; Cheng, H.; Zhao, X.; Hou, D.; Yan, Y.; Cianflone, K.; Li, M.; Mi, J. Leptin and Leptin-to-Adiponectin Ratio Predict Adiposity Gain in Nonobese Children over a Six-Year Period. Child. Obes. 2017, 13, $213-221$. [CrossRef]

56. Behiry, E.G.; El Nady, N.M.; AbdEl Haie, O.M.; Mattar, M.K.; Magdy, A. Evaluation of TG-HDL Ratio Instead of HOMA Ratio as Insulin Resistance Marker in Overweight and Children with Obesity. Endocr. Metab. Immune Disord. Drug Targets 2019, 19, 676-682. [CrossRef] [PubMed]

57. Motaghedi, R.; Gujral, S.; Sinha, S.; Sison, C.; Ten, S.; Maclaren, N.K. Insulin-like growth factor binding protein-1 to screen for insulin resistance in children. Diabetes Technol. Ther. 2007, 9, 43-51. [CrossRef] [PubMed]

58. Wallace, T.M.; Levy, J.C.; Matthews, D.R. Use and abuse of HOMA modeling. Diabetes Care 2004, 27, 1487-1495. [CrossRef] [PubMed]

59. Woodside, J.V.; Draper, J.; Lloyd, A.; McKinley, M.C. Use of biomarkers to assess fruit and vegetable intake. Proc. Nutr. Soc. 2017, 76, 308-315. [CrossRef] [PubMed]

60. Townsend, M.S.; Shilts, M.K.; Sylva, K.; Davidson, C.; Leavens, L.L. Healthy Kids a 45-Item Pictorial Assessment of Child Obesity Prevention Behaviors: Eating, Physical Activity, Screen, Sleep and Parenting. 2011. Available online: https:/townsendlab.ucdavis.edu/evaluation-research-tools/validation-research/. (accessed on 30 September 2020).

61. Townsend, M.S.; Shilts, M.K.; Diaz Rios, L.K.; Lanoue, L. Ninos Sanos, a 18-Item Pictorial Assessment of Obesity Prevention Behaviors in the Family Environment for Spanish Speakers. 2020. Available online: https: //townsendlab.ucdavis.edu/evaluation-research-tools/validation-research/ (accessed on 30 September 2020).

62. Confiac, N.; Turk, M.T.; Zoucha, R.; McFarland, M. Mexican American Parental Knowledge and Perceptions of Childhood Obesity: An Integrative Review. Hisp. Health Care Int. 2020, 18, 105-116. [CrossRef] [PubMed]

63. Freedman, D.S.; Katzmarzyk, P.T.; Dietz, W.H.; Srinivasan, S.R.; Berenson, G.S. Relation of body mass index and skinfold thicknesses to cardiovascular disease risk factors in children: The Bogalusa Heart Study. Am. J. Clin. Nutr. 2009, 90, 210-216. [CrossRef]

64. Butte, N.F.; Comuzzie, A.G.; Cai, G.; Cole, S.A.; Mehta, N.R.; Bacino, C.A. Genetic and environmental factors influencing fasting serum adiponectin in Hispanic children. J. Clin. Endocrinol. Metab. 2005, 90, 4170-4176. [CrossRef]

65. Díaz-Ríos, L.K.; Chapman-Novakofski, K.; Malacara, J.M.; Bollero, G.; Aradillas-García, C.; Garay-Sevilla, E. Metabolic and nutritional profile differences among Mexican, Mexican-American and Non-Hispanic White children. Rev. Investg. Clin. 2014, 66, 31-44.

66. Volberg, V.; Harley, K.G.; Aguilar, R.S.; Rosas, L.G.; Huen, K.; Yousefi, P.; Davé, V.; Phan, N.; Lustig, R.H.; Eskenazi, B.; et al. Associations between perinatal factors and adiponectin and leptin in 9-year-old Mexican-American children. Pediatr. Obes. 2013, 8, 454-463. [CrossRef]

67. Ruan, W.; Lai, M. Insulin-like growth factor binding protein: A possible marker for the metabolic syndrome? Acta Diabetol. 2010, 47, 5-14. [CrossRef]

68. Ibarra-Reynoso, L.d.R.; Pisarchyk, L.; Pérez-Luque, E.L.; Garay-Sevilla, M.E.; Malacara, J.M. Whole-Body and Hepatic Insulin Resistance in Obese Children. PLoS ONE 2014, 9. [CrossRef] [PubMed]

69. Beets, M.W.; Brazendale, K.; Weaver, R.G.; Armstrong, B. Rethinking Behavioral Approaches to Compliment Biological Advances to Understand the Etiology, Prevention, and Treatment of Childhood Obesity. Child. Obes. 2019, 15, 353-358. [CrossRef] [PubMed]

70. Kirkpatrick, S.I.; Baranowski, T.; Subar, A.F.; Tooze, J.A.; Frongillo, E.A. Best Practices for Conducting and Interpreting Studies to Validate Self-Report Dietary Assessment Methods. J. Acad. Nutr. Diet. 2019, 119, 1801-1816. [CrossRef] [PubMed]

71. Ontai, L.L.; Sutter, C.; Sitnick, S.; Shilts, M.K.; Townsend, M.S. Parent Food-Related Behaviors and Family-Based Dietary and Activity Environments: Associations with BMI z-Scores in Low-Income Preschoolers. Child. Obes. 2020, 16, S55-S63. [CrossRef] [PubMed]

72. Ontai, L.L.; Sutter, C.; Sitnick, S.; Shilts, M.K.; Townsend, M.S. My Child at mealtime parent self-assessment of food related behaviors: Validation with mealtime behaviors. Appetite 2019, 136, 62-69. [CrossRef] [PubMed]

73. Bekelman, T.A.; Bellows, L.L.; McCloskey, M.L.; Martin, C.K.; Johnson, S.L. Assessing dinner meals offered at home among preschoolers from low-income families with the Remote Food Photography Method. Pediatr. Obes. 2019, 14, e12558. [CrossRef] 
74. Ihmels, M.A.; Welk, G.J.; Eisenmann, J.C.; Nusser, S.M.; Myers, E.F. Prediction of BMI change in young children with the family nutrition and physical activity (FNPA) screening tool. Ann. Behav. Med. 2009, 38, 60-68. [CrossRef]

75. Yee, K.E.; Pfeiffer, K.A.; Turek, K.; Bakhoya, M.; Carlson, J.J.; Sharman, M.; Lamb, E.; Eisenmann, J.C. Association of the Family Nutrition and Physical Activity Screening Tool with Weight Status, Percent Body Fat, and Acanthosis Nigricans in Children from a Low Socioeconomic, Urban Community. Ethn. Dis. 2015, 25, 399-404. [CrossRef]

76. Dickin, K.L.; Larios, F.; Parra, P.A. Cognitive Interviewing to Enhance Comprehension and Accuracy of Responses to a Spanish-Language Nutrition Program Evaluation Tool. J. Nutr. Educ. Behav. 2015, 47, 465-471. [CrossRef]

77. Davis, R.E.; Johnson, T.P.; Lee, S.; Werner, C. Why Do Latino Survey Respondents Acquiesce? Respondent and Interviewer Characteristics as Determinants of Cultural Patterns of Acquiescence Among Latino Survey Respondents. Sage J. 2018, 53, 87-115. [CrossRef]

78. Hendrickson, S.G. Beyond translation ... cultural fit. West. J. Nurs. Res. 2003, 25, 593-608. [CrossRef] [PubMed]

79. Shilts, M.K.; Sitnick, S.L.; Ontai, L.; Townsend, M.S. Guided Goal Setting: A Feasible Obesity Prevention Behavior Change Strategy for Low-Income Parents with Young Children. J. Hum. Sci. Ext. 2018, 6, 161-179.

80. Shilts, M.K.; Townsend, M.S.; Leavens, L.; Reed, M. Healthy Kids. Available online: http://healthykids. ucdavis.edu/ (accessed on 30 September 2020).

81. Shilts, M.K.; Townsend, M.S.; Ontai, L.; Reed, M. Niños Sanos iPad Kiosk for a Medical Clinic Setting. Available online: http://healthykids.ucdavis.edu/ (accessed on 30 September 2020).

82. Shilts, M.K.; Leavens, L.L.; Trujano, J.; Lanoue, L.; Ontai, L.; Townsend, M.S. Setup a Heathy Kids iPad Kiosk Guidebook 2018. Available online: http://healthykids.ucdavis.edu/ (accessed on 30 September 2020).

83. Levie, W.H.; Lentz, R. Effects of text illustrations: A review of research. ECTJ 1982, 30, 195-232. [CrossRef]

84. Van de Vijver, F.J.R.; Leung, K. Methods and Data Analysis for Cross-Cultural Research; Sage Publications, Inc.: Thousand Oaks, CA, USA, 1997; pp. xiii, 186. ISBN 978-0-7619-0106-8.

85. Townsend, M.S.; Ganthavorn, C.; Neelon, M.; Donohue, S.; Johns, M.C. Improving the Quality of Data From EFNEP Participants With Low Literacy Skills: A Participant-driven Model. J. Nutr. Educ. Behav. 2014, 46, 309-314. [CrossRef] [PubMed]

86. Cook, T.D.; Campbell, D.T. Quasi-Experimentation: Design \& Analysis Issues for Field Settings; Houghton Mifflin: Boston, MA, USA, 1979; ISBN 978-0-395-30790-8.

87. Ontai, L.L.; Sitnick, S.L.; Shilts, M.K.; Townsend, M.S. My child at mealtime: A visually enhanced self-assessment of feeding styles for low-income parents of preschoolers. Appetite 2016, 99, 76-81. [CrossRef]

Publisher's Note: MDPI stays neutral with regard to jurisdictional claims in published maps and institutional affiliations.

(C) 2020 by the authors. Licensee MDPI, Basel, Switzerland. This article is an open access article distributed under the terms and conditions of the Creative Commons Attribution (CC BY) license (http://creativecommons.org/licenses/by/4.0/). 